U.S. DEPARTMENT OF THE INTERIOR

U.S. GEOLOGICAL SURVEY

\title{
BRECCIA-PIPE AND GEOLOGIC MAP OF THE NORTHWESTERN PART OF THE HUALAPAI INDIAN RESERVATION AND VICINITY, ARIZONA
}

By K.J. Wenrich, G.H. Billingsley, and P.W. Huntoon

Prepared in cooperation with the

U.S. BUREAU OF INDIAN AFFAIRS AND THE HUALAPAI TRIBE

Published by the U.S. Geological Survey, 1996 


\section{U.S. DEPARTMENT OF THE INTERIOR}

U.S. GEOLOGICAL SURVEY

\section{BRECCIA-PIPE AND GEOLOGIC MAP OF THE NORTHWESTERN PART OF THE HUALAPAI INDIAN RESERVATION AND VICINITY, ARIZONA}

By

Karen J. Wenrich, George H. Billingsley, and Peter W. Huntoon

Prepared in cooperation with the

U.S. Bureau of Indian Affairs and the Hualapai Tribe

Pamphlet to accompany

GEOLOGIC INVESTIGATIONS

MAP I-2522 



\section{CONTENTS}

Introduction 1

Geologic Setting 3

Structural Geology 3

Breccia Pipes 4

Introduction 4

Large Collapse Features $\cdot 5$

Cambrian and Devonian Collapse Features

5

Mineralized Breccia Pipes

6

Structural Control of Breccia Pipes

7

Surprise Canyon Formation Association with Breccia Pipes 8

Model For Breccia-pipe Formation and Mineralization $\mathbf{8}$

Acknowledgments 12

Description of Map Units 12

Surficial and Volcanic Deposits $\mathbf{1 2}$

Sedimentary Rocks $\quad 12$

Metamorphic and Igneous Rocks $\quad 15$

References $\quad 15$

\section{FIGURES}

1. Geographic map of the northwestern part of the Hualapai Indian Reservation and vicinity, Arizona.

2

2. Map showing the similar morphology of the Coconino Point and Meriwhitica Monoclines. 


\section{INTRODUCTION}

The map area encompasses about $720 \mathrm{mi}^{2}$ of (1) the northwestern part of the Hualapai Indian Reservation, (2) the western part of Grand Canyon National Park (north of the Colorado River), (3) parts of U.S. Bureau of Land Management land, (4) private land, and (5) state lands that border the western reservation boundary (fig. 1). The map area is within the southwestern Colorado Plateau physiographic province that is dissected by the Colorado River to form the Grand Canyon and its system of plateaus and tributary canyons.

The Grand Canyon separates the Hualapai Plateau (south of the Colorado River) from the Sanup and Shivwits Plateaus (north of the river; fig.1). Both the Hualapai and Sanup Plateaus are irregular-shaped plateaus of low relief; they are dissected by several deep tributary canyons to the Colorado River, most notably Spencer, Meriwhitica, Quartermaster, and Surprise Canyons. These plateaus are bounded on the west by the Grand Wash Cliffs, which also mark the physiographic break between the Colorado Plateau and the Basin and Range Province. The Sanup Plateau was connected to the Hualapai Plateau before the Grand Canyon formed (Young, 1985), and it now consists of a narrow bench between the Colorado River and the higher Shivwits Plateau to the north. An erosional scarp 1,200 ft high separates the Sanup from the higher Shivwits Plateau. Mount Dellenbaugh, a low volcanic mountain on the Shivwits Plateau, is a major landmark for aerial navigation in the western Grand Canyon region (fig. 1). All three plateaus are made up of nearly horizontally bedded Paleozoic rocks that have a regional dip averaging $1^{\circ}$ to the northeast.

Elevations range from 1,157 ft at Lake Mead to 7,072 ft at Mount Dellenbaugh on the Shivwits Plateau. The Grand Canyon has a maximum depth of $4,800 \mathrm{ft}$ (southeastern corner of map) but averages 3,600 ft deep between the Hualapai and Sanup Plateaus. Lake Mead extends $42 \mathrm{mi}$ into the western Grand Canyon to Colorado River mile 236 (fig. 1; river mileage begins at Lees Ferry, Ariz.)

Thousands of solution-collapse breccia pipes are on the Hualapai Indian Reservation and adjacent areas in northwestern Arizona. A significant number of the pipes contain $\mathrm{U}$-mineralized rock as well as anomalous concentrations of $\mathrm{Ag}, \mathrm{Co}, \mathrm{Cu}, \mathrm{Mo}, \mathrm{Ni}, \mathrm{Pb}, \mathrm{V}$, and $\mathrm{Zn}$. On the Hualapai Reservation, 886 confirmed and suspected breccia pipes have been mapped. Of these, approximately $8 \%$ show expośed mineralized rock, either as recognizable $\mathrm{Cu}$-bearing minerals, most notably malachite, azurite, or brochantite, or gamma radiation in excess of 2.5 times background. In the northwest part of the reservation (this study) 233 confirmed and suspected pipes have been identified, categorized, and located on maps A and B. Only 12 of these show gamma radiation in excess of 2.5 times background and none show any signs of Cu-bearing minerals. In the map area outside the reservation, the three-quarter-mile-diameter Grand Pipe was mapped, and an additional 223 collapse features were recognized, although most of these were not examined on the ground for mineralized rock.

Because the Paleozoic strata of northwestern Arizona contain abundant water-soluble carbonate and gypsiferous rock, numerous karst features have developed. For the purposes of studies of mineralized breccia pipes in Arizona, we have defined "breccia pipe" as those solution features which (1) formed pipe-shaped breccia bodies, (2) have potential to host U-ore, (3) bottom in the Mississippian Redwall Limestone, and (4) stoped upward through the overlying Paleozoic strata. Dissolution features whose origin or breccia content is unknown are referred to merely as "solution collapses, solution or collapse structures," or "solution features." Those that form open holes in the present ground surface, but probably do not penetrate any deeper, are termed sinkholes.

Despite periods of depressed uranium prices, the breccia pipes commanded considerable exploration activity in the 1980's because of their high-grade uranium ore deposits. Mining activity in breccia pipes of the Grand Canyon region of northern Arizona began during the nineteenth century, although at that time production was primarily for $\mathrm{Cu}$ with minor production of $\mathrm{Ag}, \mathrm{Pb}$, and $\mathrm{Zn}$. It was not until 1951 that $U$ was first recognized in the breccia pipes. During the period 1956-69, the Orphan Mine, about $50 \mathrm{mi}$ east of the map area, yielded 4.26 million $\mathrm{lb}$ of $\mathrm{U}_{3} \mathrm{O}_{8}$ with an average grade of $0.42 \% \mathrm{U}_{3} \mathrm{O}_{8}$ (Chenoweth, 1986). In addition to uranium, 6.68 million $\mathrm{lb}$ of $\mathrm{Cu}, 107,000 \mathrm{oz}$ of $\mathrm{Ag}$, and 3,400 $\mathrm{lb}$ of $\mathrm{V}_{2} \mathrm{O}_{5}$ were recovered from the ore (Chenoweth, 1986). Between 1980 and 1986 four breccia pipes were mined for uranium in northern Arizona. Ore grades from the pipes were in excess of $0.4 \% \mathrm{U}_{3} \mathrm{O}_{8}$ and production ranged from 1 to 7 million $\mathrm{lbs}$ of $\mathrm{U}_{3} \mathrm{O}_{8}$ per pipe.

With the exception of the Supai Group, all formations have been mapped as individual units. All breccia pipes bottom in the Redwall Limestone and extend into the overlying strata, with the exception of a few pipes in the Devonian Temple Butte Formation or Cambrian Muav Limestone in the area of Meriwhitica Canyon (see map A). Most of the pipes in this map area have been eroded down to the Esplanade Sandstone that caps most of the Sanup Plateau, or to the Redwall Limestone that caps the Hualapai Plateau along with isolated remnants of the lower Supai Group. It is impossible to determine if the Devonian or Cambrian pipes stoped above their host formation because the overlying strata have been eroded in the Meriwhitica Canyon area, which is the only place where such pipes have been recognized.

The entire 1,550 $\mathrm{mi}^{2}$ Hualapai Reservation was mapped at a scale of 1:48,000, and it has been divided into four companion publications that cover the northeast (Wenrich and others, in press), northwest (this map), southeast (Billingsley and others, in press a), and southwest (Billingsley and 


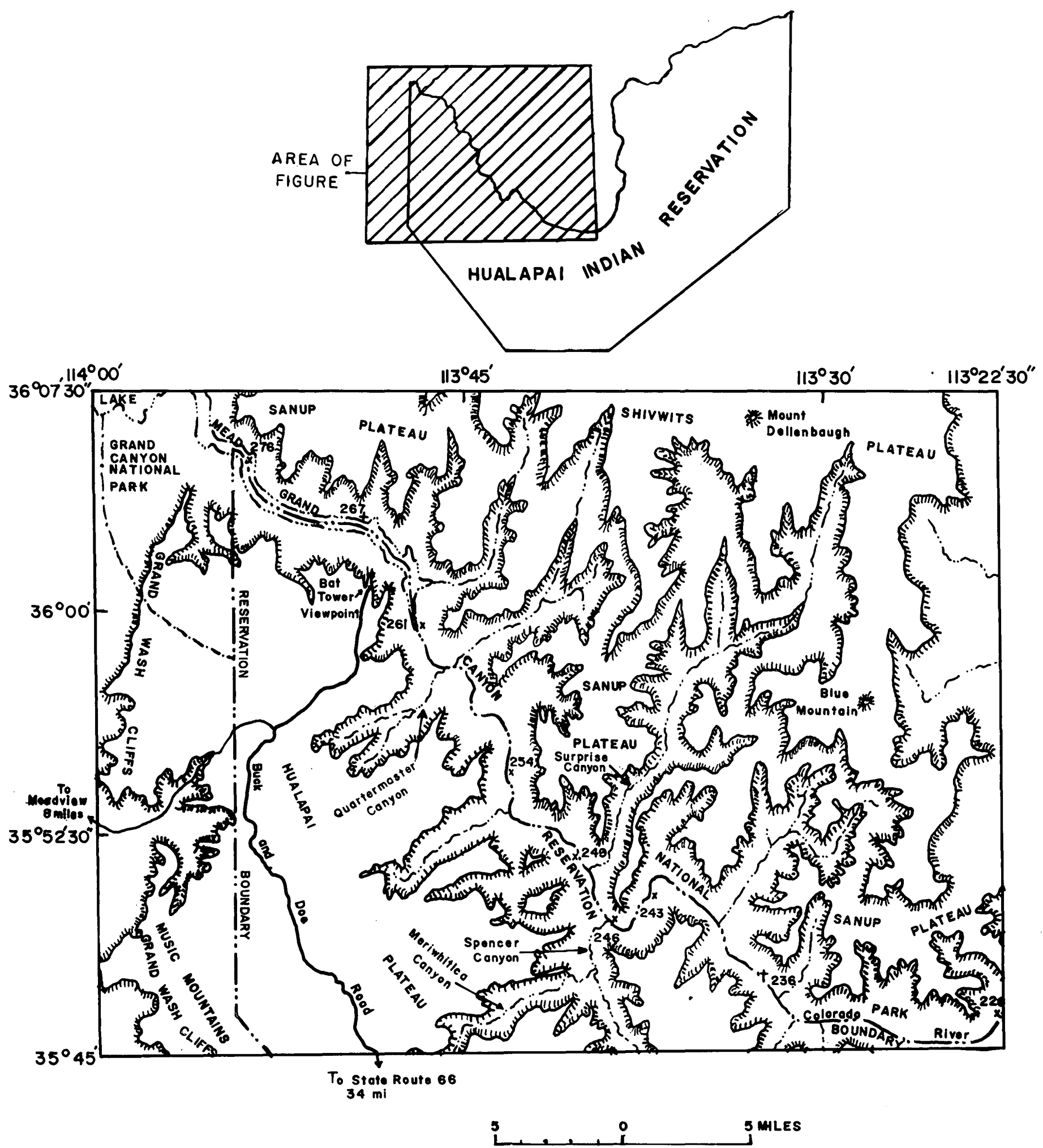

Figure 1. Geographic map of the northwestern part of the Hualapai Indian Reservation and vicinity, Arizona. River miles, which are indicated by " $x$ " and number, are referred to in the text.

others, in press b) parts of the Reservation. Each publication contains two maps: one showing the geology, including the breccia pipes (map A) coded into categories, and the other (map B) showing the breccia pipes, with their respective pipe number and category, overprinted with structures, such as faults and monoclines. Petrographic, mineralogic, 
and geochemical studies have been completed on all mineralized pipes (K.J. Wenrich, unpub. data, 1994). Initial mapping of the pipes and collapse features was done on 1:24,000 color aerial photographs. Radiometric traverses were completed on more than $90 \%$ of the mapped structures. Within the Reservation, the boundaries of all known breccia pipes and collapse features have been accurately mapped to scale. Most pipes outside the Reservation were not mapped in detail. The locations of those pipes whose boundaries were not mapped were taken from Huntoon and others (1981, 1982); such pipes are shown simply as black dots that have no relation to their true size. Several collapse features outside the Reservation were particularly well defined and thus were accurately mapped as part of this study. This research on the Hualapai Indian Reservation was funded by the U.S. Bureau of Indian Affairs in cooperation with the Hualapai Tribe in the hope that it would stimulate mining interest on Hualapai lands and would result in additional income for the Hualapai people.

\section{GEOLOGIC SETTING}

The oldest rocks in the map area are Early Proterozoic granite, schist, and gneiss exposed along the Colorado River from river mile 226 (southeast corner of map) to mile 261 just downstream from Quartermaster Canyon (fig. 1). These metamorphic rocks are mostly middle and upper amphibolite facies. Granite has intruded into the metamorphic rocks and pegmatite dikes cut granite, schist, and gneiss throughout the area.

Exposed in canyon walls and on plateaus are Paleozoic sandstone, shale, limestone, and dolomite ranging from Early Cambrian to Early Permian in age. Strata of Ordovician and Silurian age are not present in the area of the northwestern Hualapai Reservation. Their anticipated position in the section is marked by a regional disconformity that separates rocks of Cambrian and Devonian age. Devonian and Mississippian rocks are the most widely exposed Paleozoic units on the surface of the Hualapai Plateau, although at many places they are covered by Cenozoic deposits. Rocks of Pennsylvanian and Permian age form the surfaces of the Sanup Plateau. The Lower Permian Kaibab Formation forms the surface of the Shivwits Plateau that is in turn partially covered by Tertiary basalt flows.

Rocks of Mesozoic age are confined to small erosional channels cut into the Kaibab Formation in upper Surprise Canyon on the Shivwits Plateau, and along the eastern margins of the Shivwits Plateau (northeast corner of the map). These rocks consist of conglomerate of the Timpoweap Member and the lower red member of the Moenkopi Formation (Early Triassic age).

Cenozoic deposits, ranging from Paleocene to Holocene in age, cover much of the Paleozoic section of the
Hualapai Plateau. Tertiary basalt and andesitic basalt cover large areas of the Shivwits Plateau and parts of the Hualapai Plateau. In the tributary canyons of the Grand Canyon, Cenozoic deposits are limited to landslide debris, travertine, and talus.

The oldest Cenozoic deposits in the map area are probably gravel deposited in Tertiary paleovalleys between Quartermaster and Spencer Canyons. This ancient valley sediment is partially preserved by Tertiary basalt flows. The music mountain and buck and doe conglomerates, described by Young (1966, p. 26), consist primarily of Proterozoic and Paleozoic clasts. The deposits are considered to be Paleocene to Pliocene, though they may be older because of its apparent stratigraphic position below gravel that, a few miles east of the map area, contains Eocene gastropods (Young, 1985).

In Peach Springs and Milkweed Canyons similar conglomerate and fanglomerate occupy a similar stratigraphic position (Young, 1966; Young and Brennan, 1974). Where Cenozoic rocks are exposed in Peach Springs Canyon, the conglomerate interfingers with gravel similar to that east of the map area, as described by Koons (1948, 1964).

On the Hualapai Plateau, Miocene and older sedimentary deposits are commonly covered with basalt flows and tuff of Miocene age. The Peach Springs Tuff, just south of the map area, (Young, 1966, 1970, and 1979) yielded a Miocene age of 18.3 million years (Damon, 1968). Basalt flows (Pliocene and younger) cover large areas of the Harrisburg Member of the Kaibab Formation, lower members of the Moenkopi Formation, and thin undefined gravel deposits on the Shivwits Plateau. Post-Miocene lag gravel deposits are composed of mixed Precambrian and Paleozoic clasts, and were formed by erosion, mixing, and redeposition of older gravel deposits as well as local erosion of Precambrian and Paleozoic rocks. These deposits are locally found in small abandoned tributary or "cutoff" drainages on the Hualapai Plateau.

A few remnants of a Pleistocene basalt flow that followed the Colorado River are preserved in the map area (river miles 243, 246, 249, and 254; fig. 1). They are all that remain of a flow that extended at least $74 \mathrm{mi}$ from its upstream source (Hamblin, 1970). The travertine deposits in Meriwhitica, Spencer, and Quartermaster Canyons, and along the Colorado River (river miles 267 to 276; fig. 1) are the largest accumulations of travertine in the Grand Canyon except for those at Havasu Canyon in the south-central part of Grand Canyon, and Royal Arch Creek at eastern Grand Canyon.

\section{STRUCTURAL GEOLOGY}

The generalized structural geology of the entire Hualapai Indian Reservation and vicinity is discussed in detail in 
Wenrich and others (in press). This summary includes a tectonic overview and discussions of the deformation of the Paleozoic section, Laramide monoclines, late Cenozoic faulting, and Cenozoic uplift and erosion.

Two north-trending, east-dipping monoclines are within the map area, the Horse Flat Monocline in the southwest, and the Meriwhitica Monocline that cuts through the center of the map area. The Horse Flat Monocline is a minor fold that has a few hundred feet of structural offset. The Meriwhitica Monocline is unusually well exposed and has over 1,000 ft of structural offset in the map area. The Meriwhitica Monocline is cored by a reactivated Precambrian basement fault that is well exposed adjacent to the Colorado River on the south wall of Reference Point Canyon. Here the basement fault is a high-angle reverse fault, which has propagated upward into the Cambrian rocks. The cross-sectional views provided in Reference Point and Clay Tank Canyons reveal that the synclinal and anticlinal axial planes of the fold converge downward on the basement fault. Hence, the monocline is seen to die out with depth. Conversely, its width increases with elevation so that at the level of the top of the Redwall Limestone, the fold is almost $1 \mathrm{mi}$ wide as measured between the anticlinal and synclinal hinges. The rocks involved in the fold deformed ductilely, demonstrating that the Paleozoic rocks were buried under a substantial thickness of overburden at the time the monocline developed. The Meriwhitica and Horse Flat Monoclines were not downfaulted to the west in late Cenozoic time as were the Hurricane and Toroweap Monoclines (Wenrich and others, in press) east of the map area.

The normal faults in the map area have north, northeast, and northwest trends. The greatest displacement of strata found in the area is along the buried Grand Wash Fault in the northwest corner of the map area. The Grand Wash Fault displaced Paleozoic strata as much as $10,000 \mathrm{ft}$ at this location before burial by the upper part of the synorogenic Miocene Muddy Creek Formation (Lucchitta, 1979). The age of the onset of extensional faulting along the Grand Wash Fault may have been as early as Miocene (Young and Brennan, 1974).

Most offsets attenuate with depth in the series of north-trending grabens east of the Grand Pipe (collapse structure 288; maps A and B) in the northwest corner of the map area. This relationship is revealed by the fact that the density of faults diminishes at the level of the Cambrian exposures along Lake Mead. The origin of the fault zone is east-west extension, as determined by the northerly strikes of the faults and vertical slickensides found along the fault surfaces. The carbonate rocks comprising the plateau surfaces failed through brittle fracturing, whereas the underlying Cambrian rocks deformed ductiley through minor attenuation of bed thickness and folding.

The Dellenbaugh Fault and other smaller north-trending faults on the Shivwits Plateau are most notable because they displace Pliocene basalt flows. The Dellenbaugh Fault exhibits a record of recurrent displacements because the underlying Paleozoic rocks are displaced more than the overlying volcanic rocks.

\section{BRECCIA PIPES}

\section{INTRODUCTION}

The map area includes 456 breccia pipes and solution collapse features (map B): (1) 233 mapped collapse features are within the reservation boundary, (2) 31 mapped collapse features are outside, but adjacent to, the western and southwestern reservation boundary, (3) 61 unmapped breccia pipes (breccia was observed within the feature) are outside the reservation (designated with a "B"), and (4) 131 unmapped collapse features also are outside the reservation (designated with a " $\mathrm{C}$ "). Although the rock exposure is excellent in the map area, the massive nature of the Redwall Limestone commonly makes it difficult to recognize surface indications of collapse features, such as inward-tilting beds, on the Hualapai Plateau. Of the 264 mapped collapse features, 12 were found to have gamma radiation in excess of 2.5 times background. None were found to have surface exposure of $\mathrm{Cu}, \mathrm{Pb}$, or $\mathrm{Zn}$ minerals. Because all of the 224 collapse features within the reservation boundary are on that part of the Hualapai Plateau surface formed primarily by the Mississippian Redwall Limestone, or remnants of the overlying lower Supai Group, they are breccia pipes by our definition because they bottom in the Redwall Limestone. The same is true for those features mapped on the Sanup Plateau surface formed by the Lower Permian Esplanade Sandstone or Pakoon Limestone. In contrast, some of those on the Shivwits Plateau may well be shallower collapse features that represent gypsum dissolution within the Lower Permian Toroweap or Kaibab Formations. Further discussions on the mineralogy, geochemistry, and origin of the breccia pipes can be found in Wenrich $(1985,1986 \mathrm{a})$ and Wenrich and Sutphin (1989).

This map contains no mapped collapse features on Permian plateau surfaces. Nevertheless, to maintain a constant classification between the four companion maps of the Reservation, the collapse features were classified similarly to those that crop out on the Permian plateau surfaces. Because it is difficult to distinguish breccia pipes from gypsum collapses on Permian plateau surfaces where little breccia is exposed, circular features were classified on such physical characteristics as (1) the presence of concentric inward-dipping beds, (2) altered rock (specifically, bleached and limonite-stained), (3) brecciated rock, (4) mineralized rock, and (5) pattern of circular vegetation or circular topographic anomalies. Clasts ranging in size from millimeters to boulders, imbedded within a finely comminuted sandstone matrix, comprise the brecciated rock; all clasts are rock that has been dropped from an overlying stratigraphic horizon. Because the breccia pipes have probably undergone considerable 
flushing by ground water solutions, the matrix is generally composed of finely comminuted sand grains and minor carbonate cement.

Delineating the exact outline of the breccia pipe in the field is difficult unless the breccia column itself is exposed. Such exposure is not uncommon along the cliffs of the Grand Canyon and its tributaries but is rare on the adjacent plateaus. Because the brecciated column of rock within each pipe abuts against generally well-stratified, relatively undeformed sedimentary rock, the plane demarking this contact is by definition a fracture, referred to here as the ring fracture (Wenrich, 1985). More properly, it should be termed the inner ring fracture, because the stratified sedimentary rock surrounding the breccia column commonly contains a series of concentric ring fractures that are not as well defined as the inner ring fracture. Because the inner ring fracture is well exposed in less than half of the mapped collapse features, and in order to be consistent throughout the map area, the boundaries of the breccia pipes were mapped as the outermost extent (where exposed) of the inward-dipping strata.

\section{LARGE COLLAPSE FEATURES}

All known breccia pipes contain a column of breccia less than $300 \mathrm{ft}$ in diameter; however, many collapses such as the Shadow Mountain Collapse (1 mi due north of Shadow Mountain; see fig. 2, Wenrich, 1985) on the Marble Plateau, and the Grand Pipe, in the northwest corner of the map area, are over $0.5 \mathrm{mi}$ in diameter. Such large collapse features exposed on plateau surfaces are not uncommon; a good example of such a collapse feature underlain by a confirmed breccia pipe is the Pigeon Pipe, east of Kanab Creek on the Kaibab Plateau, north rim of the Grand Canyon (see fig. 2, Wenrich, 1985). This pipe was mined for uranium, producing several million pounds of $\mathrm{U}_{3} \mathrm{O}_{8}$ during the late 1980's. The collapse feature exposed on the plateau surface at the Pigeon Mine is about $0.5 \mathrm{mi}$ in diameter, yet the actual size of the pipe is less than $300 \mathrm{ft}$ in diameter. This enlarged collapse above and around the breccia pipes is due to dissolution of upper Paleozoic soluble units, such as the gypsiferous Woods Ranch Member of the Toroweap Formation and the limestone and gypsum within the Harrisburg Member of the Kaibab Formation. Such dissolution has a negative impact on the breccia-pipe mapping process by creating solution collapses that may be totally unrelated to breccia pipes. However, it also aids in mapping by enhancing the surface expression of those features, such as the Pigeon Pipe, that are indeed breccia pipes. Yet, dissolution of overlying soluble units cannot explain the large collapse features on the Hualapai Plateau, Grand Pipe, or Shadow Mountain Collapse. On the Marble Plateau, where the Shadow Mountain Collapse is located, there are no extensive soluble units in the Toroweap or Kaibab Formations. Large collapse features, such as the Grand Pipe
(Sanup Plateau) and some pipes on the Hualapai Plateau are below soluble upper Paleozoic strata.

In addition to the Grand Pipe, there are at least three other collapse features shown on map B that are over $0.5 \mathrm{mi}$ in diameter: 387,401 , and 714 . Perhaps the clue to how such large -features formed can be found in feature 387 . Collapse features $388,389,390,391,414$, and 425 form a ring around the larger feature 387 (map B). This same scenario is on the northeast map (Wenrich and others, in press) at feature 232. These large collapse features appear to have formed by the coalescing of several small solution features, or breccia pipes. If breccia pipes are present within these large collapse features, it is unlikely that they are larger than $300 \mathrm{ft}$ in diameter. All three features $(387,401$, and 714; map B) are on the Redwall Limestone surface and there has obviously been significant downdropping of the overlying strata because both 387 and 401 have Pennsylvanian red beds preserved within their centers.

The Grand Pipe (fig. 4e, Wenrich, 1986b; Huntoon and others, 1982) is one of the best examples of how dissolution of the Redwall Limestone can result in overlying strata forming a closed depression with concentrically inward-dipping beds: Here the Esplanade Sandstone dips $3-7^{\circ}$ concentrically inward toward the center of the feature that is filled with downdropped (along a ring fractureshown on map A) concentrically inward-dipping (dips as much as $30^{\circ}$ ) Hermit Shale. In places the rock is extensively bleached and stained with secondary pinkish hematite. On the north-northeast side of the pipe, an outcrop with abundant black manganese oxide and limonite staining contains gamma radiation slightly in excess of 2.5 times background. Brecciated rock was also observed at this location. Goethite nodules associated with celadonite are exposed within this part of the pipe. Tertiary lava flowed from a dike down into the depression over the inward-dipping strata on the southwest side of the pipe. This is only one of three pipes mapped by the authors that have lava associated with them, but the lava is clearly younger than the collapse feature because it flowed into the depression.

\section{CAMBRIAN AND DEVONIAN COLLAPSE FEATURES}

Although no breccia pipes are known to go below the base of the Whitmore Wash Member of the Mississippian Redwall Limestone, 11 collapse features have been observed in the Middle Cambrian Muav Limestone and seven in the Middle(?) and Upper Devonian Temple Butte Formation. Seven of these features contain breccia, and several form distinct brecciated columns of rock that look similar in morphology to the Bat Cave breccia pipe (for photograph, see fig. 1 in Wenrich, 1985). All are on surfaces that have been eroded below the Redwall Limestone, so it is impossible to determine whether they stoped above the Devonian rocks. Nevertheless, because such collapse 
features are not believed to be related to breccia pipes that formed economic uranium deposits, they will not be referred to here as breccia pipes.

The breccia in feature 702 is cemented by clear calcite that readily forms float composed of rhombs of transparent calcite. In some of the features, such as 704 and 718 , stalactitic calcite resembling that deposited as travertine from hot springs, but more crystalline, cements the breccia clasts. Neither the stalactitic nor clear calcite varieties are common within the breccia pipes.

\section{MINERALIZED BRECCIA PIPES}

None of those 12 pipes that have been labeled as mineralized on the map (map B) contain $\mathrm{Cu}, \mathrm{Pb}$, or $\mathrm{Zn}$ minerals exposed on the surface. Ten of the 12 are on the Hualapai Reservation, while the Grand Pipe (288) is on the north rim along the west edge of the map area and 293 is just west of the reservation boundary near the top of the Grand Wash Cliffs. All of the "mineralized rock" was classified as such because it emits anomalous gamma radiation, which ranges from 15 times background in black shale of the Upper Mississippian Surprise Canyon Formation along the ring fracture zone of the Bat Cave Pipe (360), to barely more than two times background in pipes 345 and 352 . All but feature 293 have breccia exposed within them and are clearly breccia pipes. Each of these mineralized pipes shows some limonite alteration and bleaching of the downdropped Watahomigi Formation of the Supai Group or the Surprise Canyon Formation.

These mineralized pipes, with the exception of the Grand Pipe, have been stripped of all overlying strata down to the basal part of the Supai Group (the Watahomigi Formation) or Surprise Canyon Formation. This denudation of the pipes results in essentially little potential for economic uranium deposits, as all breccia pipes mined to date have their ore within Lower Permian and Upper Pennsylvanian sandstone. In addition, the total volume of rock remaining in the pipe is probably insufficient to host an orebody. None of the collapse features labeled with only a "B" or " $C$ " on the map, have been examined in the field for mineralized rock. Several of these collapse features and pipes are on the Shivwits Plateau and contain a complete section of preserved Paleozoic rocks, but most of the 190 such features are on the Sanup Plateau that is capped by the Esplanade Sandstone, which is a good host for uranium mineralization.

Some of the mineralized pipes on the Hualapai Plateau, although of little economic value, are of scientific interest. The Bat Cave Pipe (360) provides one of the best cross sectional views (fig. 1, Wenrich, 1985) of a breccia pipe in the Grand Canyon. Pulverized black shale of the Surprise Canyon Formation along the south side of the ring fracture emits gamma radiation 8 times background; bleached greenish-white sandstone along the north side of the ring fracture emits counts exceeding 15 times background. Pipe
252 is adjacent to the Bat Cave Pipe on the back side of the cliff (map B). Although the two may be a single pipe, the geometry suggests that they are separate, but possibly related features. Most of the Bat Cave Pipe is exposed on the cliff but it probably does not extend through the cliff to the other side.

Pipes 340, 345, and 349 (map B) have abundant goethite nodules, which, on the higher plateaus, are a good pathfinder for mineralized breccia pipes. Perhaps these pipes originally were overlain by mineralized sandstone. Downdropped Surprise Canyon Formation in pipe 340 contains abundant limonite pseudomorphs after pyrite, silicified sandstone, bright-yellow limonite staining, and anomalous gamma radioactivity of 5 times background associated with iron-rich areas. The second most radioactive pipe in the map area is 405 in the upper reaches of Jeff Canyon, west central part of map B. Gamma radioactivity reaches 12 times background along a Mn-stained bed in the Redwall Limestone, which is an unusual host for anomalous gamma counts. These values are particularly high for the surface exposure of a breccia pipe, and unusual for limestone.

The anomalous gamma radioactivity within the other mineralized pipes appears to be associated with black shale of the Surprise Canyon Formation. Black shale is more organic-rich than any other rock within the breccia pipes, so it is possible that this anomalous radioactivity is characteristic of black shale in or near a permeable zone such as that afforded by the breccia pipe.

The surface morphology of pipe 226 provides an excellent three-dimensional view (fig. 5, Wenrich, 1985) of a closed circular depression overlying a column of breccia. Unfortunately, there is limited exposure of the ring fracture, and the highest gamma radioactivity emitted at the surface was only two times background. Alteration and secondary mineralization include bleaching of sandstones of the Watahomigi and Surprise Canyon, limonite, hematite, and goethite and specular hematite nodules. Calcite crystals and veins are common. The breccia consists of bleached sandstone in a red hematitic sandstone matrix. Measurements of five primary fluid inclusions in dolomite crystals provided filling temperatures of $140-161^{\circ} \mathrm{C}$. These data fall within the $86-173^{\circ} \mathrm{C}$ range of measurements taken from sphalerite found in breccia-pipe orebodies.

\section{STRUCTURAL CONTROL OF BRECCIA PIPES}

In contrast to the breccia pipes on the Marble Plateau (Sutphin and Wenrich, 1988) there are no obvious northeast or northwest alignments of pipes in the map area. There are three possible N. $40^{\circ}$ E. alignments (map A) extending through (1) six features (with thrce or more within one-eighth mi of the alignment) from 324 to 345.5 to a collapse feature labeled "B" on the north rim; (2) eight features from 385 to 413 to a collapse feature labeled " $\mathrm{B}$ " on the north rim; and (3) seven features from 702 to 685 to a feature 
labeled " $\mathrm{C}$ " on the north rim. In addition, there is one possible N. $50^{\circ} \mathrm{W}$. alignment of 10 features from 686 to 332 to a feature labeled " $\mathrm{C}$ " just northwest of the reservation. There are two possible short N. $10^{\circ} \mathrm{W}$. to N. $20^{\circ} \mathrm{W}$. alignments between features 307 to 329 and 345 to 365 . The N. $50^{\circ} \mathrm{W}$. and $\mathrm{N} .40^{\circ} \mathrm{E}$. trends are similar in direction to those found on the Marble Plateau. For most of the map area the distribution of breccia pipes appears to be random.

Joint sets in the Redwall Limestone were found by Huntoon (1970, p. 105) to consist of a "system of regularly spaced master joints in a rectilinear network that extends up to five miles on either side of major faults." The major joints within the Redwall along the Bright Angel Fault system trend northwest and northeast. A study of joints on the Redwall Limestone-capped Hualapai Plateau showed that northeast- and northwest-trending fracture sets may have been imposed upon the Redwall prior to deposition of the overlying Pennsylvanian and Lower Permian Supai Group (Roller, 1987). The northeast-trending fracture set averages approximately N. $50^{\circ}$ E. and the northwest set averages $\mathrm{N}$. $45^{\circ} \mathrm{W}$. (Roller, 1987). It is important to emphasize that these orientations are similar to the few breccia-pipe alignments on the map. These northwest- and northeast-trending fractures apparently localized ground-water movement during Mississippian time and exerted significant control on the development of the Redwall Limestone karst. It is also possible that some of the Redwall karst developed prior to these fracture systems. In some breccia pipes, beds of Watahomigi and Surprise Canyon Formation thicken within the pipes, indicating that the beds were deposited into karst topography (Billingsley, 1986). Perhaps the dissolution responsible for the upward stoping that created the breccia pipes occurred much later, subsequent to the development of northwest and northeast fracture systems. Many of the breccia pipes that contain exposed beds of Upper Mississippian Surprise Canyon and Middle and Lower Pennsylvanian Watahomigi Formations do not exhibit obvious thickening of the beds, suggesting that the breccia pipe collapse occurred subsequent to deposition of these formations. This later development of breccia pipes might account for the paucity of alignments of collapse features on the Redwall Limestone surface, where if anything they should be more numerous, because none would be "lost" by incomplete stoping to the top of the Kaibab surface. Many of the collapse features on the Hualapai Plateau surface may have formed prior to deposition of the Pennsylvanian sediment, and perhaps were choked by Late Mississippian sediment (Billingsley, 1986), preventing continued stoping.

Although there is not a direct association between breccia pipes and monoclines, the locations of both appear to be controlled by basement fault blocks. Shoemaker and others (1978) reported that major fault zones and lineaments defined by alignments of cinder cones and fault traces on the Colorado Plateau show preferred northeast and northwest trends. They believe that these fault systems probably extend deep within the Earth's crust and have been active since Precambrian time. The monoclines are Laramide reactivations of these earlier faults (Huntoon, 1989; Wenrich and others, in press). The stresses within the upper crust, and the resultant fracturing of the rocks that formed the monoclines, were apparently consistent across the $75 \mathrm{mi}$ of Colorado Plateau between the Marble Plateau and the Hualapai Plateau. These basement stresses resulted in two monoclines, the Coconino Point and Meriwhitica, which are $75 \mathrm{mi}$ apart and have similar geometry (fig. 2).

Breccia pipes are more concentrated in areas where monoclines bifurcate (fig. 2). Because pipe localization predates the Laramide monoclines, clustering of pipes along the Laramide and post-Laramide structures suggests that the Precambrian faults underlying and localizing these younger structures were part of the same process that aided the upward propagation of fractures important for pipe formation. Such fracturing occurred long before the basement faults were reactivated to the extent that overlying strata failed through faulting or folding. The similar morphology of monoclines and accompanying localization of breccia pipes throughout the Grand Canyon region suggests that whatever structural control was exerted by the basement on both monoclines and breccia pipes, such control was uniform across the entire region.

\section{SURPRISE CANYON FORMATION ASSOCIATION WITH BRECCIA PIPES}

The breccia pipes, particularly mineralized breccia pipes, tend to be in clusters throughout northern Arizona. Seven of the 12 mineralized pipes shown on map B are in the Bat Cave Pipe area. This area is also the site of a major ancestral paleovalley of the Surprise Canyon Formation. The Surprise Canyon Formation appears to be more important to breccia-pipe exploration than previously thought. Unfortunately, paleovalleys and tributary paleovalleys of the Surprise Canyon Formation are hidden beneath most of the plateau surfaces where breccia pipes have been mined. More than $40 \%$ of the breccia pipes exposed in the Redwall Limestone on the Hualapai Reservation have either Surprise Canyon strata dipping into the pipe or contain breccia clasts composed of Surprise Canyon. The association of breccia pipes and Surprise Canyon paleovalleys is probably due to the dependance of both on high rates of ground water and stream discharge capable of creating extensive valleys and karst topography. It is also probable that the migrating solutions which mineralized the breccia pipes followed the Surprise Canyon Formation using it as a channelway between pipes that were connected by the same Surprise Canyon paleovalley. Thus, a map showing Surprise Canyon paleovalleys across northwest Arizona would provide the exploration geologist with the Late Mississippian paleogradient, which might indicate areas of greatest breccia-pipe density. 


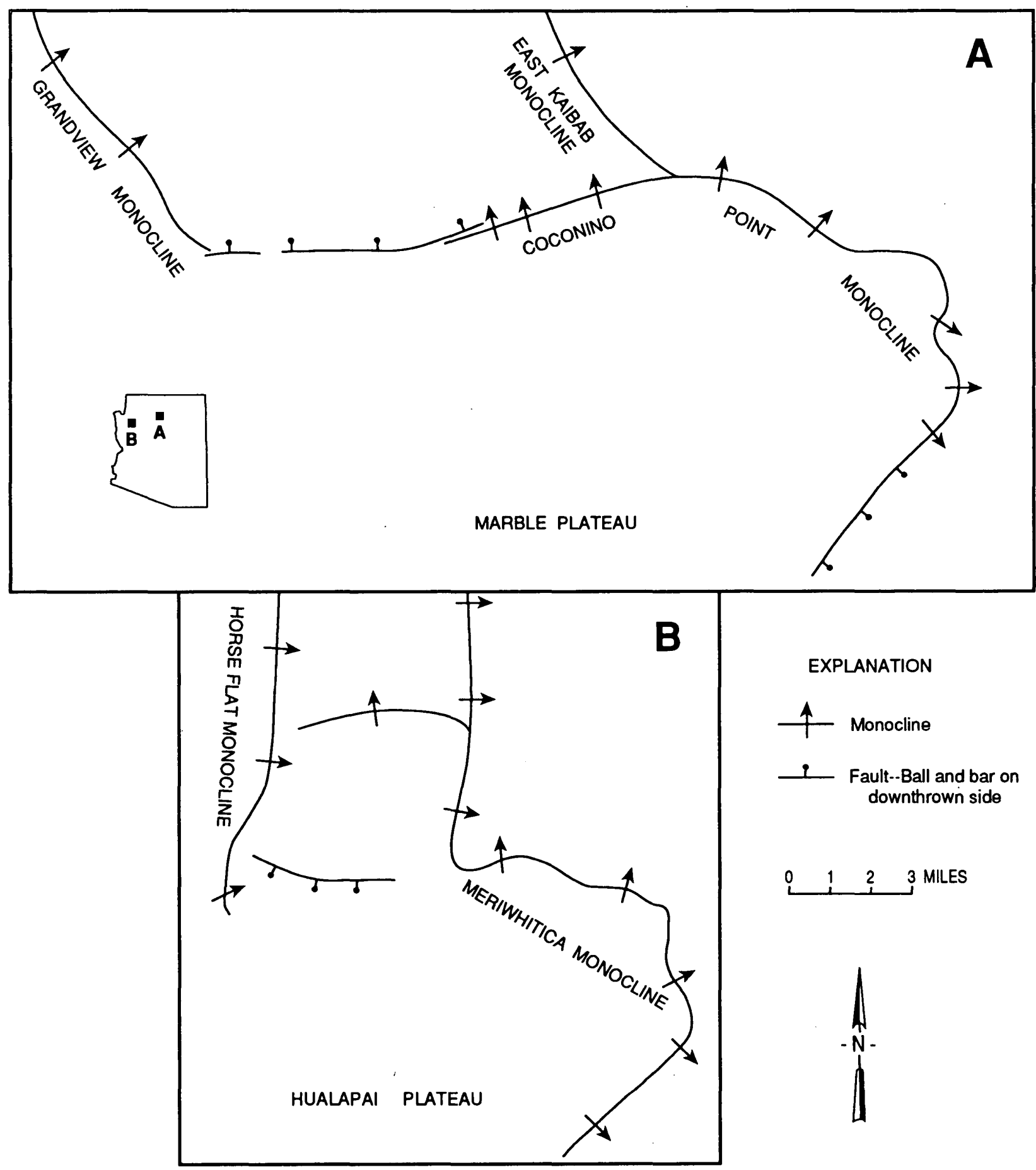

Figure 2. Map showing the similar morphology of the Coconino Point and Meriwhitica Monoclines. The Coconino Point Monocline is on the Marble Plateau 75 miles east of the map area at the eastern edge of the breccia-pipe province, and the Meriwhitica Monocline is on the Hualapai Plateau at the western edge of the breccia-pipe province.

\section{MODEL FOR BRECCIA-PIPE FORMATION AND MINERALIZATION}

The breccia-pipe-forming process began as early as Late Mississippian time (Billingsley, 1986), shortly after deposition of the Redwall Limestone, but was completed by Early Jurassic time. The youngest age of the uraninite ore is 200-220 Ma (Ludwig and Simmons, 1992). These U-, Cu-, $\mathrm{V}-, \mathrm{Pb}-, \mathrm{Zn}-, \mathrm{Ni}-, \mathrm{Co}-$, and Ag-bearing breccia pipes (metals listed in decreasing order of economic potential) may have 
evolved during the following sequence of events (events with the same number may have been concurrent, or their sequence is not obvious):

1a. Development of karst in the Redwall Limestone shortly after its deposition (Billingsley, 1986).

1b. Fracturing of the Redwall Limestone by two joint sets averaging N. $50^{\circ}$ E. and $N .45^{\circ}$ W. (Roller, 1987). Because ancient karst features presently exposed on the Redwall Limestone surface (Hualapai Plateau) do not form obvious northeast and northwest alignments, it is possible that the earliest Redwall karst formed prior to development of these northeast and northwest joint sets.

2. Deposition of the Upper Mississippian Surprise Canyon and Lower and Middle Pennsylvanian Watahomigi Formations on and within the karst surface. Much of this sediment clogged cave passages (Billingsley, 1986) and perhaps prevented later upward stoping of many filled karst features.

3a. Deposition of overlying Paleozoic and Triassic strata up through the Upper Triassic Chinle Formation. During the late Paleozoic, northwestern Arizona remained tectonically stable and sediment was deposited on flat-lying surfaces. This stability provided a very low hydraulic gradient and probably permitted little movement of connate waters within the sediment. Streams flowed approximately westward or southwestward across northwestern Arizona during Late Mississippian through Permian time (Billingsley and Beus, 1985).

3b. Upward stoping of Redwall Limestone caverns causing collapse and brecciation of the overlying strata. This process could have begun shortly after the close of the Mississippian and continued upward throughout the late Paleozoic and Triassic; however, it is more likely that most stoping and brecciation did not occur until after lithification of the overlying units, because there is little obvious evidence in most breccia pipes for soft-sediment deformation. The only well-documented exception to this is in the Harrisburg Member of the Kaibab Formation, which filled depressions in the underlying Fossil Mountain Member. Sandstone beds of the Harrisburg in the upper $60 \mathrm{ft}$ of the Sage Pipe are thicker than equivalent units outside the pipe (Brown and others, 1992). A similar scenario in the Harrisburg was observed at the Arizona 1 Pipe (Robert Schafter, oral commun., Geol. Soc. of Amer. Meeting, Denver, 1988). These pipe locations are shown in fig. 1 of Wenrich and others (in press). Brown and others (1992) also believe that formation of the Sage Pipe began during or shortly after deposition of the Supai Group because they observed $50 \mathrm{ft}$ of thinning in the upper part of the
Esplanade Sandstone on the northern side of the pipe and a corresponding thickening of the Hermit Shale section. These observations indicate that some subsidence was occurring at least intermittently throughout the Paleozoic, although the thinning of the Esplanade could have been a result of decementation during the hiatus between the Esplanade and Hermit, rather than a depositional process during deposition of the Esplanade.

(1) Joint control of the karst. The extent of joint control on breccia-pipe formation is not clear. Breccia pipes on the Marble Plateau are reasonably well aligned in northeast and northwest trends (Sutphin and Wenrich, 1988). However, on the Hualapai Plateau (this map), no such alignments are obvious. It is possible that the clogging of the early karst system (event 1a, above) in the Redwall Limestone with sediment of the Surprise Canyon Formation prevented upward stoping and hence, alignment of these collapses that did stope upward. If the northeast and northwest fracture pattern had developed subsequent to the earliest karst formation (event 1b), then the breccia pipes might align in northeast and northwest directions, while localized collapse features in the Redwall created by this earliest karst event would not be aligned in such directions. Dissolution of karst features at intersections of northeast and northwest fractures might have been due to later reactivation of the karst. Such fractures probably localized ground-water movement and exerted significant, but not complete, control on the breccia-pipe stoping process. Major faults in northern Arizona that have been periodically reactivated since the Precambrian (Huntoon, 1970) are generally oriented in the same northwest and northeast directions; a good example is the Mesa Butte Fault that trends northeast across the Marble Plateau. Such prominent northwest and northeast trends suggest that basement-induced fractures in the Redwall Limestone influenced the location of breccia pipes.

(2) Breccia-pipe development prior to jointing in strata overlying the Redwall Limestone. A detailed joint orientation study at the Ridenour Mine, in the northeastern part of the Hualapai Reservation (Wenrich and others, in press), revealed that the breccia-pipe ring fracture formed prior to any jointing in the Lower Permian Esplanade Sandstone (Verbeek and others, 1988). This observation was supported by the work of J.A. Roller (1987) who established "that the northeast- and northwest-trending fracture sets (F1 and F2) in the Redwall Limestone do not have correlatives in the Supai Group." Although Roller studied only one location, she reported that the "one station studied 
in the Surprise Canyon Formation suggests the possibility that the Surprise Canyon Formation contains the early $F 1$ and F2 sets of the Redwall Limestone." If the above observations are correct, the sequence of events would have progressed as described in events $1 \mathrm{a}$ and $1 \mathrm{~b}$-the location of the later breccia-pipe stoping (event $3 b$ ) would have been influenced by northeast and northwest fractures, whereas the early karst filled by Surprise Canyon Formation (Billingsley, 1986) would not have been influenced by these fractures. The lack of jointing in the Supai and younger rocks at the time of breccia pipe formation accounts for the circular nature of the breccia pipes rather than an elliptical or square morphology elongated along fractures.

4. Uplift of sediment. "The full effects of the various pre-Jurassic orogenies along the continental margins upon the basement block beneath Arizona are not yet well understood" (Dickinson, 1989). Late in the Triassic Period, a magmatic arc formed across southwestern Arizona and extended northwestward into southeastern California and western Nevada. Large quantities of gravel and sand were transported northwestward across northwestern Arizona by streams that originated in the uplifted flank of Precambrian and Paleozoic rocks (Mogollon Highlands) on the back or northeast side of the magmatic arc (Bilodeau, 1986). Blakey (1989, fig 5) shows an "early Mogollon Highlands" as early as during Moenkopi deposition (early Triassic). These highlands provided a steep hydrologic gradient for the first time since the Mississippian, so that brine trapped in Upper Paleozoic beds, particularly Mississippian and Pennsylvanian limestones, could migrate northward down the hydrologic gradient. Assuming Ludwig and Simmons (1992) are correct and mineralization began as early as 260 $\mathrm{Ma}$, one wonders if some form of uplift might have began as early as $260 \mathrm{Ma}$.

5. Development of a basin in northwestern Arizona. "There was a significant fluvial and deltaic basin in the Cameron area during deposition of the [Upper Triassic] Shinarump and Petrified Forest Members of the Chinle Formation. Significant fluctuations in lake level, and associated ground-water level, occurred in response to both seasonal and longer-term climatic fluctuations, in part due to the tropical monsoonal climate and its long-term intensity variations. These hydrologic fluctuations resulted in significant 'pumping' in the system" (Dubiel, R.F., written commun., 1986). This "pumping" of the hydrologic system is known to accentuate karst development today in northern Florida.
The migration of brine fluids may have been accelerated by sudden development or at least enlargement of the breccia pipes during the Triassic. It is possible that there may not have been such a large province of breccia pipes until the Late Triassic. This sudden brecciation of the pipes during the Late Triassic, accompanied by regional uplift to the south and resultant relatively steep hydrologic gradient, probably provided fluids from multiple aquifers with a highly permeable conduit for their movement and mixing. The hydrologic gradient would have been upward within the sedimentary basin (Huntoon, 1986). The breccia pipes undoubtedly formed excellent conduits for upward movement of previously trapped connate waters from any of the Paleozoic aquifers above the base of the Redwall within the basin setting in northwest Arizona. In fact, metal-rich fluids also could have migrated upward from the Precambrian basement through major northeast- and northwest-trending high-angle fracture systems into pipes that intersect the fracture sets-perhaps explaining the clustering of mineralized pipes. Alternatively, since the Redwall Limestone and other upper Paleozoic aquifers were in contact with the Precambrian basement in the Mogollon Highlands, Precambrian rocks there could have been the source for metal-rich fluids that migrated through the Paleozoic aquifers. Ludwig and Simmons (1992) found that $\mathrm{Pb}$ isotopes in galenas indicated that fluids which passed through mineralized pipes had interacted with the Proterozoic basement.

Location of the ore within breccia pipes may well have been controlled by the local hydrologic gradient. This might explain why ore in the Orphan and Canyon Mines (South Rim), located primarily in the Supai Group and Hermit Shale, is stratigraphically lower than most North Rim ores that are rarely in the Supai, but, rather, are higher in the Hermit and Coconino. Perhaps North Rim ore deposition occurred closer to the axis of the basin, and although the ore is stratigraphically higher the pipe itself would have been topographically lower.

6. Mineralization. Mississippi Valley-type ore deposits formed in the matrix between breccia fragments. Metals contained in connate waters that began to flow during tilting of the crust in surrounding northern Arizona probably formed these orebodies. Deposition of the first and second stages (events $6 \mathrm{a}$ and $6 \mathrm{~b}$ ) of mineralization clearly preceded uraninite deposition (Wenrich and Sutphin, 1989), which occurred at two separate intervals, $260 \mathrm{Ma}$ (Canyon and Pinenut Pipes) and $200 \pm 20 \mathrm{Ma}$ (Hack 2 and 3, Kanab North, and EZ1 and 2) (Ludwig and Simmons, 1992). The older 
age of $260 \mathrm{Ma}$ places the earlier uraninite mineralization approximately at the close of the Harrisburg Member of the Kaibab Formation (prior to any Triassic events-items 4 and 5 above). This age eliminates any possibility that volcanic ash in the Triassic Chinle Formation was the source for the earliest uraninite mineralization (such as at the Canyon, Pinenut, and Orphan Pipes, where the youngest possible mineralization is 220 Ma; Ludwig and Simmons, 1992).

a. First stage of mineralization. Deposition of coarsely crystalline calcite, dolomite, and barite preceded all ore mineralization.

b. Second stage of mineralization. Minerals rich in $\mathrm{Ni}, \mathrm{Co}, \mathrm{As}, \mathrm{Fe}$, and $\mathrm{S}$ (siegenite, bravoite, pyrite, millerite, Fe-siegenite, cobaltian pyrite, niccolite, rammelsbergite, pararammelsbergite, gersdorffite, Co-gersdorffite, arsenopyrite, and marcasite) predate the uraninite (Wenrich and Sutphin, 1989). It was during this stage that the "pyrite cap" over the orebody probably formed; this impervious cap was instrumental in the preservation of the uranium orebodies during the past $200 \mathrm{Ma}$.

c. Third stage of mineralization. Fe- $\mathrm{Zn}-\mathrm{Pb}$ sulfides and $\mathrm{Cu}$ sulfides (galena, sphalerite, pyrite, lautite, chalcopyrite, enargite, and tennantite) formed next. Additional calcite was deposited and the first phase of uraninite mineralization began. Uraninite was generally precipitated later than most of the other minerals in this stage.

In some pipes a phase of pyrobitumen (85.6\% carbon, $3.74 \%$ sulfur, and hydrogen) was introduced prior to deposition of sphalerite and uraninite (Wenrich and Sutphin, 1989). The sulfide-rich Mississippi Valley-type ore already present in the breccia pipes would have provided an excellent reductant for any uranium being transported in oxidizing ground water. Alternatively, although hydrocarbons are known to be poor reductants for uranium, it is possible that $\mathrm{H}_{2} \mathrm{~S}$ associated with the pyrobitumen would have been the uranium reductant as well as the reducing medium that commonly bleached the Hermit and Supai redbeds within, and adjacent to, the breccia pipes. $\mathrm{H}_{2} \mathrm{~S}$ is a likely reductant to form barite, pyrite, $\mathrm{Ni}$-Co sulfides, and other sulfide minerals. (Gornitz and others, 1987). If the reducing $\mathrm{H}_{2} \mathrm{~S}$ was related to the pyrobitumen it is peculiar that most pipes, such as the Orphan and Sage Pipes, are virtually barren of pyrobitumen. It is more likely that as a result of uplift the $\mathrm{H}_{2} \mathrm{~S}$ migrated from marine sediment, as did connate water, toward the axis of the basin and up some of the breccia pipe conduits. Pyrobitumen may be unrelated to uraninite precipitation. Furthermore, the Mississippi Valley-type ores were abundant and consistently available as a reductant for uranium within all mineralized pipes.

The uraninite age of $200 \pm 20 \mathrm{Ma}$ (Ludwig and Simmons, 1992) allows for a Triassic or possibly earliest Jurassic source rock. Although no Triassic or older volcanic rocks have been identified in the hypothesized source region farther south, more mapping, age determinations, and palinspastic restorations need to be made on rocks from this part of Arizona before the nature of the source terrane can be adequately understood. It is conceivable that the uranium source rocks were Precambrian granite, but lack of granitic materials in Chinle Formation pebble suites (Dodge, 1973) suggests that such rocks were not exposed in the Mogollon Highlands source region. However, as with the galenas, fluids which formed the uraninite may have traveled through the granite and into the Paleozoic aquifers. As with the connate waters, movement of ground water from these highlands through any of the aquifers would have been toward the axis of the basin and then up the breccia pipes. However it is also possible that the uranium source was merely average composition Colorado Plateau ground water that was flushed in large volume through the porous breccia pipes, with their effective reductants facilitating the concentration of high grade uraninite (Wenrich and others, 1989).

7. Oxidation of some orebodies. Later oxidation of breccia-pipe orebodies occurred, particularly along the edge of the Colorado Plateau, such as at the Grand Gulch Mine (about 10 mi north-northeast of the Grand Pipe-shown on this map) and in the Basin and Range Province (at breccia pipes such as the Apex Mine in the Beaver Dam Mountains of southwest Utah). It is probable that the uraniniteand sulfide-rich orebodies remained intact until the pyrite caps were destroyed. Pyrite cap destruction occurred most extensively along the western edge of the breccia- pipe province where canyon dissection and erosion has been more intense. Canyon dissection during the past 5 million years has permitted downward percolation of oxidizing ground water, removing protective pyrite caps and oxidizing the orebodies. Minerals such as malachite, azurite, brochantite, cyanotrichite, chrysocolla, hemimorphite, smithsonite, metazeunerite, and goethite formed in these secondary zones of mineralization.

Better preservation of uranium orebodies has occurred in areas farthest from the margin of the Colorado Plateau, particularly on the high plateaus capped by the Kaibab, Moenkopi, or Chinle Formations, such as the Coconino Plateau in the Hualapai Reservation (Wenrich and others, in press; 
Billingsley and others, in press a). Thus, even if orebodies in breccia pipes on the Hualapai Plateau had not been removed by erosion, it is likely that the ore would have been oxidized and the uranium dispersed by ground water.

\section{ACKNOWLEDGMENTS}

The authors are indebted to Bradley S. Van Gosen for the care with which he compiled and plotted the breccia-pipe data. Without his help these maps would not have been as accurate nor as timely. Hoyt B. Sutphin provided mapping assistance in the early stages of this project. His continued assistance, enthusiasm, and exchange of ideas made this project a success. Richard A. Young unselfishly contributed his Cenozoic stratigraphic knowledge to help establish a better correlation between various gravel deposits. Review suggestions by Fred Peterson and F.G. Poole improved the manuscript. Also a special thanks to Mike Bertoldi and Dana Morris of Grand Canyon Helicopters for safely and competently transporting us in hazardous flying conditions to various locations in the study area. This project was funded by the U.S. Bureau of Indian Affairs in cooperation with the Hualapai Indian Tribe.

\section{DESCRIPTION OF MAP UNITS}

\section{SURFICIAL AND VOLCANIC DEPOSITS}

Qal

Alluvial Deposits (Holocene)-Unconsolidated fluvial deposits of silt, sand, gravel, and boulders; includes eolian and flood-plain deposits. Faults shown bounding alluvium do not offset alluvium

Qc Colluvium (Holocene and Pleistocene?)Consists of brecciated rock fragments, boulders, gravel, sand, and silt; partly consolidated; contains gypsiferous or calcareous cement. Includes alluvial-fan and landslide debris. Faults shown bounding colluvium do not offset colluvium

Qt Travertine deposits (Holocene and Pleistocene)-Spring deposits of calcium carbonate. Includes angular boulders, gravel, sand, and silt from adjacent talus deposits

$\mathrm{Qb}$

Basalt flows (Pleistocene)-Olivine basalt; exhibits radial and columnar cooling joints along the Colorado River (river mile 243, 246,249 , and 254)

QTI Landslides (Pleistocene)-Unsorted and unconsolidated material. In the Grand Canyon, consists mainly of large blocks of Paleozoic sedimentary rock that have slid downward and rotated toward the base of the parent wall. On the Shivwits Plateau margin, consists of a jumbled, unconsolidated mixture of basalt, and beds of the Harrisburg Member of the Kaibab Formation and the lower part of the Moenkopi Formation

Younger gravel (Pleistocene to Miocene)Well-rounded gravel, sand, and silt from older gravel deposits of Proterozoic and Paleozoic clastic material mixed with angular chert and limestone clasts derived from local outcrops of Cambrian to Pennsylvanian rocks. Clasts are matrix supported, cemented with calcium carbonate. Includes the willow springs formation of Young (1966, p. 26). Unit commonly covered by thin colluvium or caliche. Thickness as much as $120 \mathrm{ft}$

$\mathrm{Ti}$ Intrusive volcanic rocks (Pliocene and Miocene)-Alkali olivine basalt and andesitic dikes and plugs

Tb Basalt and andesite basalt flows (Pliocene and Miocene)-Basalt and andesite flows on the Shivwits Plateau surrounding the Blue Mountain and Mount Dellenbaugh areas

Tc Basaltic cinder deposits (Pliocene and Miocene)-Basalt cinder cones on the Shivwits and Hualapai Plateaus

Tv Volcanic deposits (Pliocene and Miocene)Volcanic deposits on the Hualapai Plateau; includes the Peach Springs Tuff of Young (1966, 1979); basalt flows, agglomerate, fluvial volcanic-bearing sediment, and coarsegrained pyroclastic deposits near vent areas

\section{SEDIMENTARY ROCKS}

Tmc Muddy Creek Formation (Miocene)—Poorly consolidated to well-consolidated, poorly bedded deposits of light-gray conglomerate and fanglomerate interbedded with pinkishtan siltstone, mudstone, and sandstone. Thickness unknown, but probably several thousand feet

Fanglomerate and undifferentiated gravel (Pliocene? through Paleocene?)-Conglomerate, breccia, fanglomerate, gravel, sand, silt, and limestone. Fills older drainages on the Hualapai Plateau. Includes the music mountain conglomerate, westwater formation, and buck and doe conglomerate of Young (1966, p. 26). Lag gravel makes it difficult to distinguish the stratigraphic sequence in areas of low relief. Often overlain by volcanic deposits (Tv). Unconformably overlies Cambrian, Devonian, 
Mississippian, and Pennsylvanian rocks

Moenkopi Formation (Lower Triassic)Includes lower red member and Timpoweap Member as defined by Stewart and others (1972)

Lower red member and Timpoweap Member, undivided-Light-gray and pale reddish-gray conglomerate; includes reddish-gray siltstone and sandstone. Light-gray, rounded, fossiliferous limestone and chert cobbles as much as 5 in. in diameter are locally derived from Kaibab Formation. Fills erosional channels cut into Kaibab Formation. Unconformably overlies Kaibab Formation. Unconformably overlain by Tertiary volcanic rocks in the Mount Dellenbaugh area. Forms slope. Thickness as much as $200 \mathrm{ft}$

Pk Kaibab Formation (Lower Permian)Includes, in descending order, Harrisburg and Fossil Mountain Members as defined by Sorauf and Billingsley (1991). Divided into:

Harrisburg Member-Yellowish-gray to pale-red shale, red sandstone, and gypsiferous gray siltstone interbedded with gray to yellowish-gray fossiliferous limestone, dolomitic sandstone, silicified chert, and thick layers of gray-white gypsum. Forms alternating cliffs and slopes, but typically forms slopes. Locally covered by landslide blocks of Tertiary basalt and Moenkopi Formation along eastern edge of Shivwits Plateau. Truncated by Tertiary erosion; thickest deposits in northeast part of map area. Gradational contact with underlying Fossil Mountain Member. Thickness 0 to more than $350 \mathrm{ft}$

Fossil Mountain Member-Light-gray, cherty limestone, sandy dolomite, and limestone. Unconformably overlies Toroweap Formation. Forms cliff. Thickness averages $250 \mathrm{ft}$

Toroweap Formation (Lower Permian)Includes, in descending order, Woods Ranch, Brady Canyon, and Seligman Members as defined by Sorauf and Billingsley (1991). Divided into:

Woods Ranch Member-Gypsiferous, pale-red and gray siltstone and sandstone. Includes thin beds of dark-gray limestone; locally absent where dissolution has occurred along canyon walls of the Shivwits Plateau. Forms slope. Thickness 90-100 ft

Brady Canyon Member-Dark- to light-gray, medium-bedded, fossiliferous limestone. Forms cliff. Thickness $200-250 \mathrm{ft}$
Seligman Member-Yellowish-white to pale-red, thin-bedded sandstone. Forms slope or recess in cliff. Unconformably overlies Coconino Sandstone in southeast part of map area; unconformably overlies Hermit Shale in northwest part of map area. Thickness 30-70 ft

Pc Coconino Sandstone (Lower Permian)Light-brown to yellowish-red, fine-grained, large-scale, cross-stratified sandstone. Forms cliff. Locally absent or discontinuous in western two-thirds of map area but thickens to $100 \mathrm{ft}$ along southeastern edge of the Shivwits Plateau. Unconformably overlies Hermit Shale. Thickness $0-100 \mathrm{ft}$

Ph Hermit Shale (Lower Permian)-Red-brown and white, thin-bedded, fine-grained, siltstone and sandstone; mostly covered by colluvium and talus debris. Forms slope. Unconformably overlies Esplanade Sandstone. Thickness averages about $700 \mathrm{ft}$ in eastern half of map area, increasing to nearly $1,000 \mathrm{ft}$ along western edge of map area

Pep Esplanade Sandstone of the Supai Group and Pakoon Limestone (Lower Permian)-As defined by McKee (1982). The lower Esplanade Sandstone is a slope-forming, pale-red to reddish-orange, thin-bedded siltstone and sandstone sequence less than $50 \mathrm{ft}$ thick. It is overlain by a middle unit of pale-red, cross-stratified, medium- to fine-grained, medium-bedded, cliff-forming sandstone that intertongues with gray, thick-bedded, fossiliferous limestone beds of the Pakoon Limestone of McNair (1951). The Pakoon Limestone beds, near the eastern margin of the map area, are commonly $10 \mathrm{ft}$ thick and intertongue with crossbedded sandstone of the Esplanade, becoming thicker in northwest part of map area, forming a cliff about $200 \mathrm{ft}$ thick within the Esplanade Sandstone cliff. The Pakoon is overlain by an upper unit that consists of $100 \mathrm{ft}$ of ledge-forming Esplanade Sandstone followed by about 200 $\mathrm{ft}$ of slope-forming, red siltstone capped by a white to pale-red, fine-grained sandstone ledge. Unconformably overlies Wescogame Formation. Thickness averages $400 \mathrm{ft}$ at eastern edge of map area, increasing to nearly $600 \mathrm{ft}$ at the northwestern edge of map area

Pwmw Lower part of Supai Group (Pennsylvanian)Includes, in descending order, Wescogame, Manakacha, and Watahomigi Formations as defined by McKee $(1975,1982)$ 
Wescogame Formation (Upper Pennsylvanian)-Pale-red to gray siltstone, shale, limestone, and dolomite interbedded with grayish-red calcareous sandstone. Forms slope in upper part, cliff in lower part. Unconformably overlies Manakacha Formation. Average thickness $130 \mathrm{ft}$

Manakacha Formation (Middle Pennsylvanian)-Reddish-brown, fine-grained, thickbedded, crossbedded dolomitic sandstone interbedded with gray, medium-grained, crossbedded dolomite and thin-bedded gray limestone; contains thin red-brown siltstone beds. Forms slope and ledges in upper part, cliff in lower part. Unconformably overlies Watahomigi Formation. Thickness about $200 \mathrm{ft}$ at east edge of map area, increasing to about $250 \mathrm{ft}$ at northwest edge of map area

Watahomigi Formation (Middle and Lower Pennsylvanian)-Purple-gray to gray siltstone and fine-grained sandstone interbedded with gray, thin- to medium-bedded limestone. Limestone beds include red chert lenses. Forms ledges in slope. A purple siltstone, containing some conglomerate and thin-bedded limestone beds, is near the base. A thick-bedded, gray, fossiliferous limestone in lower part thickens westward, forming a cliff. Unconformably overlies Surprise Canyon Formation or Redwall Limestone. Average thickness about $230 \mathrm{ft}$

Ms Surprise Canyon Formation (Upper Mississippian)-Consists of an upper slope- and ledge-forming, dark-red-brown, thin-bedded, fine-grained siltstone and sandstone and laminated thin beds of silty limestone; a middle cliff-forming, yellowish-gray, coarsely crystalline, silty, friable, thin-bedded, fossiliferous limestone; and a lower ledge or slope of chert-pebble conglomerate and sandstone. Conglomerate is clast supported in dark-redbrown to black, iron-stained sandstone matrix. Deposited in caves and fluvial paleovalleys eroded into underlying Redwall Limestone. Unconformably overlies Redwall Limestone. Thickness ranges from about $5-400 \mathrm{ft}$

$\mathrm{Mr} \quad$ Redwall Limestone (Upper and Lower Mississippian)-As defined by McKee (1963). Consists of Horseshoe Mesa, Mooney Falls, Thunder Springs, and Whitmore Wash Members, undivided. All members form a continuous sheer cliff with a slight recess at the contact between the Horseshoe Mesa and Mooney Falls Members. All four mem-

bers consist of light-gray, thick-bedded, aphanitic limestone and dolomite; contains marine fossils throughout. White chert bands are common in the Thunder Springs Member. Unconformably overlies Temple Butte Formation. Thickness as much $300-700 \mathrm{ft}$

Dtb

$€ m$

Eba
Temple Butte Formation (Upper and Middle? Devonian)-Interbedded dark-gray to purple-gray, medium-bedded dolomite, dolomitic sandstone, sandy limestone, reddish-brown siltstone, and gray siltstone. Disconformably overlies Muav Limestone. Forms slope with ledges. Thickness $450 \mathrm{ft}$

Tonto Group (Middle and Lower Cambrian)-As defined by McKee and Resser (1945). Divided into:

Muav Limestone (Middle Cambrian)Mottled gray and purple, thin-bedded dolomitic limestone; weathers rusty gray. Includes white to light-gray beds of unnamed dolomite as much as $450 \mathrm{ft}$ thick between Muav Limestone and overlying Temple Butte Formation. Limestone ledges and low cliffs are separated by beds of slope-forming green shale lithologically similar to underlying Bright Angel Shale. Base of unit marked at base of Rampart Cave Member of Muav Limestone, forming disconformable contact with Bright Angel Shale. Thickness about 900 to as much as $1,200 \mathrm{ft}$

Bright Angel Shale (Middle Cambrian)Green and purplish-red, fissile shale interbedded with light-brown to reddishbrown, coarse-grained, thin-bedded sandstone beds of Tapeats lithology. Also interbedded with rusty-brown dolomitic tongues of Muav Limestone. Includes a coarse-grained, purple-red sandstone (redbrown member of McKee and Resser, 1945). Lower contact with the Tapeats Sandstone is arbitrarily placed at or near the top of Tapeats Sandstone cliff. Lower part contains abundant thin beds of light-brown sandstone of Tapeats lithology. Forms slope and red-brown sandstone ledge at about the middle of unit. Thickness about $350 \mathrm{ft}$

Tapeats Sandstone (Middle and Lower Cambrian)-Light-gray to light-brown and red-purple, medium- to coarse-grained, medium-bedded sandstone and smallpebble conglomerate. Silica cement gives appearance of quartzite. Includes low-angle crossbeds and thin, green shale partings 
between sandstone beds in upper part. Unconformably overlies Proterozoic rocks. Forms cliff. Thickness 100-200 ft

\section{METAMORPHIC AND IGNEOUS ROCKS}

Vishnu Group (Early Proterozoic)-As defined by M.P. Clark (Huntoon and others, 1981, 1982)

Xgr Nonfoliated granitic plutons-Brown to light-red holocrystalline, quartz-bearing granite pluton

Xgrf Foliated granitic plutons-Light-colored, coarse-grained plutonic granite with feldspar and mafic minerals

Xvs Mica schist-Mica and quartz, mainly muscovite and biotite

Xva Mafic schist and amphibolite-Very fine grained, foliated; contains dark-colored minerals; also contains amphibole and plagioclase and sparse quartz

Xvm Paragneiss-Granular feldspar and quartz alternating with lenticular micaceous layers and fine-grained amphibole minerals

$\mathrm{Xu}$ Proterozoic undivided-Brown to reddish-brown, holocrystalline, quartz-bearing granite plutons, very fine grained foliated schist, gneiss, and quartz-feldspar pegmatites

\section{REFERENCES}

Billingsley, G.H., 1986, Relations of the Surprise Canyon and Watahomigi Formations to breccia pipes in the Grand Canyon, Arizona [abs.]: Geological Society of America Abstracts with Programs, v. 18, no. 5, p. 342.

Billingsley, G.H., and Beus., S.S., 1985, The Surprise Canyon Formation-An Upper Mississippian and Lower Pennsylvanian (?) rock unit in the Grand Canyon, Arizona: Stratigraphic Notes, 1984, U.S. Geological Survey Bulletin 1605-A, p. A27-A33.

Billingsley, G.H., and Huntoon, P.W., 1983, Geologic map of the Vulcan's Throne and vicinity, western Grand Canyon, Arizona: Grand Canyon Natural History Association, Grand Canyon, Arizona, scale 1:48,000.

Billingsley, G.H., Wenrich, K.J., and Huntoon, P.W., in press a, Breccia-pipe and geologic map of the southeastern part of the Hualapai Indian Reservation and vicinity, Arizona: U.S. Geological Survey Geologic Investigations Map, scale 1:48,000.

Billingsley, G.H., Wenrich, K.J., Huntoon, P.W., and Young, R.A., in press b, Breccia-pipe and geologic map of the southwestern part of the Hualapai Indian Reservation and vicinity, Arizona: U.S. Geological Survey Geologic Investigations Map I-2554, scale 1:48,000.
Bilodeau, W.L., 1986, The Mesozoic Mogollon highlands, Arizona-an Early Cretaceous rift shoulder: Journal of Geology, v. 94, p. 724-735.

Blakey, R.C., 1989, Triassic and Jurassic Geology of the Southern Colorado Plateau, in Jenney, J.P., and Reynolds, S.J. eds., Geologic evolution of Arizona: Arizona Geological Society Digest 17, p. 369-396.

Brown, N.A., Mead, R.H., and McMurray, J.M., 1992, Relationship between collapse history and ore distribution in the Sage breccia pipe, northwestern Arizona, in K.A. Dickinson, Short papers of the U.S. Geological Survey uranium workshop, 1990: U.S. Geological Survey Circular 1069 , p. 54-56.

Chenoweth, W.L., 1986, The Orphan Lode Mine, Grand Canyon, Arizona, a case history of a mineralized, collapse-breccia pipe: U.S. Geological Survey Open-File Report 86-510, 126 p.

Damon, P.E., 1968, Correlation and chronology of ore deposits and volcanic rocks: Annual Progress Report no. COD-689-100, Contract (11-1)-689, Research Division, U.S. Atomic Energy Commission, p. 49-50.

Dickinson, W.R., 1989, Tectonic setting of Arizona through geologic time, in Jenny, J.P., and Reynolds, S.J., eds., Geologic evolution of Arizona: Arizona Geological Society Digest 17, p. 1-16.

Dodge, C.N., 1973, Pebbles in the Chinle and Morrison Formations: New Mexico Geological Society Guidebook, p. 114-121.

Gornitz, Vivian, Wenrich, K.J., Sutphin, H.B., and Buden, R.V., 1987, Origin of the Orphan Mine breccia pipe uranium deposit, Grand Canyon, Arizona: Proceedings of Annual Meeting of the American Institute of Mining Engineers, 1987, p. 281-301.

Hamblin, W.K., 1970, Late Cenozoic basalt flows of the western Grand Canyon region, in Hamblin, W.K., and Best, M.G., eds., The western Grand Canyon district: Utah Geological Society, Guidebook to the geology of Utah, no. 23, p. 21-37.

Huntoon, P.W., 1970, The hydro-mechanics of the ground water system in the southern portion of the Kaibab Plateau, Arizona: Tucson, Arizona, University of Arizona, Ph.D. thesis, $251 \mathrm{p}$.

1986, Ground water flow directions in the Colorado Plateau breccia pipes: Geological Society of America abstracts with programs, v. 18, no. 5, p. 363.

Huntoon, P.W., Billingsley, G.H., and Clark, M.D., 1981, Geologic map of the Hurricane Fault zone and vicinity, western Grand Canyon, Arizona: Grand Canyon Natural History Association, Grand Canyon, Arizona, scale 1:48,000.

1982, Geologic map of the lower Granite Gorge and vicinity, western Grand Canyon, Arizona: Grand Canyon Natural History Association, Grand Canyon, Arizona, scale 1:48,000. 
Koons, D., 1948, Geology of the eastern Hualapai Reservation: Museum of Northern Arizona Bulletin (Plateau), v. 20 , no. 4 , p. $53-60$.

1964, Structure of the eastern Hualapai Indian Reservation, Arizona: Arizona Geological Society Digest, v. 7, p. 97-114.

Lucchitta, Ivo, 1979, Late Cenozoic uplift of the southwestern Colorado Plateau and adjacent lower Colorado River region: Tectonophysics, v. 61, p, 63-95.

Ludwig, K.R., and Simmons, K.R., 1992, U-Pb dating of uranium deposits in collapse breccia pipes of the Grand Canyon region: Economic Geology, v. 87, p. 1747-1765.

McKee, E.D., 1963, Nomenclature for lithologic subdivisions of the Mississippian Redwall Limestone, Arizona: U.S. Geological Survey Professional Paper 475-C, p. 21-22.

McKee, E.D., 1975, The Supai Group-subdivisions and nomenclature: U.S. Geological Survey Bulletin 1395-J, p. 1-11.

McKee, E.D., 1982, The Supai Group of Grand Canyon: U.S. Geological Survey Professional Paper 1173, 504 p.

McKee, E.D., and Resser, C.E., 1945, Cambrian history of the Grand Canyon region: Carnegie Institute, Washington, Publication 563, $232 \mathrm{p}$.

McNair, A.H., 1951, Paleozoic stratigraphy of northwestern Arizona: American Association of Petroleum Geologists Bulletin 35, p. 503-541.

Roller, J.A., 1987, Fracture history of the Redwall Limestone and lower Supai Group, western Hualapai Indian Reservation, northwestern Arizona: U.S. Geological Survey Open-File Report 87-0359, 33 p.

Shoemaker, E.M., Squires, R.L., and Abrams, M.J., 1978, The Bright Angel and Mesa Butte Fault systems of northern Arizona, in Smith, R.B., and Eaton, G.D., eds., Cenozoic tectonics and regional geophysics of the western Cordillera: Geological Society of America Memoir 152, p. 341-368.

Stewart, J.H., Poole, F.G., and Wilson, R.F., 1972, Stratigraphy of the Triassic Moenkopi Formation and related strata in the Colorado Plateau region, with a section on sedimentary petrology by Cadigan, R.A., U.S. Geological Survey Professional Paper 691, 195 p.

Sorauf, J.E., and Billingsley, G.H., 1991, Members of the Toroweap and Kaibab Formation, Lower Permian, northern Arizona and southwestern Utah: Rocky Mountain Geologist, v. 28, no. 1, p. 9-24.

Sutphin, H.B., and Wenrich, K.J., 1988, Map showing structural control of breccia pipes on the southern Marble Plateau, north-central Arizona: U.S. Geological Survey Miscellaneous Investigations Series Map I-1778, scale $1: 50,000$.

Verbeek, E.R., Grout, M.A., and Van Gosen, B.S., 1988, Structural evolution of a Grand Canyon breccia pipe; the Ridenour copper-vanadium-uranium mine, Hualapai Indian Reservation, Coconino County, Arizona: U.S. Geological Survey Open-File Report 88-006, 75 p.

Wenrich, K.J., 1985, Mineralization of breccia pipes in northern Arizona: Economic Geology, v. 80, no. 6, p. 1722-1735.

1986a, Geochemical exploration for mineralized breccia pipes in northern Arizona, U.S.A.: Applied Geochemistry, v. 1, no. 4, p. 469-485.

1986b, Uranium mineralization of collapse breccia pipes in northern Arizona, Western United States, in Helmut Fuchs, ed., Vein type uranium deposits: International Atomic Energy Agency IAEA-TECDOC-361, p. 395-414.

Wenrich, K.J., Billingsley, G.H., and Huntoon, P.W., in press, Breccia pipe and geologic map of the northeastern part of the Hualapai Indian Reservation and vicinity, Arizona: U.S. Geological Survey Geologic Investigations Map I-2440, scale 1:48,000.

Wenrich K.J., Chenoweth, W.L., Finch, W.I., and Scarborough, R.B., 1989, in Jenny, J.P., and Reynolds, S.J., eds., Geologic evolution of Arizona: Arizona Geological Society Digest 17, p. 759-794.

Wenrich, K.J., and Sutphin, H.B., 1989, Lithotectonic controls necessary for formation of a uranium-rich, solution-collapse breccia-pipe province, Grand Canyon Region, Arizona, in Metallogenesis of uranium deposits: Proceedings of a technical committee meeting on metallogenesis of uranium deposits organized by the International Atomic Energy Agency and held in Vienna, March 9-12, 1987: Vienna, Austria, International Atomic Energy Agency, p. 307-344.

Young, R.A., 1966, Cenozoic geology along the edge of the Colorado Plateau in northwestern Arizona: Spokane, Washington, Washington University, Ph.D. dissertation, $167 \mathrm{p}$.

1979, Laramide deformation, erosion and plutonism along the southwestern margin of the Colorado Plateau: Tectonophysics, v. 61 , nos. $1-3$, p. 25-47.

1985, Geomorphic evolution of the Colorado Plateau margin in west-central Arizona; a tectonic model to distinguish between the causes of rapid, symmetrical scarp retreat and scarp dissection, in Morisawa, M., and Hack, J.T., eds., Tectonic Geomorphology: 15th Annual Binghamton Geomorphology Symposium, September 1985, Part 2, p. 261-278.

Young, R.A., and Brennan, W.J., 1974, Peach Springs tuff, its bearing on structural evolution of the Colorado Plateau and development of Cenozoic drainage in Mohave County, Arizona: Geological Society of America Bulletin, v. 85, p. 83-90. 